\title{
ACCOUNTING FOR MANUFACTURING OUTPUT IN NIGERIAN ECONOMIC GROWTH: KALDORIAN APPROACH WITH THE NEW INTERPRETATION
}

\author{
Prof. Usman, O.A. (PhD) \\ Department of Management and Accounting, \\ Ladoke Akintola University of Technology, \\ Ogbomoso, Oyo State. Nigeria.
}

\begin{abstract}
The study investigated the applicability of Kadorian approach to measure the effect of Nigerian manufacturing output on economic growth with new interpretation. Time series data from 1981 to 2016 were collected and used from CBN bulletin. Ordinary least square method is employed to examine the impact of manufacturing outputs on economic growth and also its impact on exports. The results of the study showed that there was a strong relationship between manufacturing output and economic growth and likewise, there was strong relationship between manufacturing output and export. The new interpretation says that there must have been relationship between manufacturing output and export before it could be said that there is relationship between the manufacturing output and economic growth, invariably, new interpretation of Kaldorian approach is also held in Nigeria. The paper therefore, recommends that manufacturing sectors should be encouraged, expanded and controlled for continual production of quality products that will be attracting external demands so as to record increasing exports.
\end{abstract}

Keywords: Manufacturing sector, Economic growth, Export, Kaldor

\section{INTRODUCTION}

The manufacturing sector of Nigerian economy has plausibly been seen as the engine of the country's economic transformation over the years. Significantly, the sector has been moving into an emerging industrial developmental tool from a casual and rudimentary agricultural economy that can hardly be ignored no matter how buoyant the manufacturing

\author{
Adebayo Moses \\ Department of Management and Accounting, \\ Ladoke Akintola University of Technology, \\ Ogbomoso, Oyo State, Nigeria.
}

sector is. Successive governments have continued to play a catalytic role through policies and provision of financial facilities to elevate the sector to position that can make Nigeria an economic wheel and a driver of African economy. It is proven to see that currently, most countries that were at the same or even lower stage of development to Nigeria decades ago such as Malaysia have transformed their real sectors beyond mean performance (Roslina, 2005).

The propagation of manufacturing companies in the country will extend to impact the Foreign Direct Investment to other countries (outflow) which is made feasible thorough involvement in industrialization policy. (Inegbenebor, 1995) corroborated the above that 'the manufacturing sector plays a catalytic role in a modem economy and has many dynamic benefits crucial for economic transformation. In any advanced economy or even growing economy, the manufacturing sector is a leading sector in many respects. It is an avenue for increasing productivity in relation to import replacement and export expansion, creating foreign exchange earning capacity, rising employment and per capita income, which causes unique consumption patterns.

Furthermore, it creates investment capital at a faster rate than any other sector in the economy while promoting wider and more effective linkages among different sectors. (Loto, 2012) said in his study on performance of manufacturing sector that, the sector has been contributing to the Gross Domestic Products, the manufacturing sector is recognized, but it has been overtaken by the services sector in a number of countries, including Nigeria. He further said, before independence, agricultural production dominated Nigeria's economy and accounted for the major share of its foreign earnings. Early efforts in the manufacturing sector were oriented towards the 


\section{International Journal of Engineering Applied Sciences and Technology, 2019 \\ Vol. 4, Issue 5, ISSN No. 2455-2143, Pages 56-63 \\ Published Online September 2019 in IJEAST (http://www.ijeast.com)}

adoption of an import substitution strategy in which light industry and assembly related manufacturing ventures were embarked upon by the former trading companies. Up to about 1970 the prime mover in the manufacturing activities was the private sector which established some agro-based light manufacturing units, such as vegetable oil extraction, plants, tobacco etc. The import-dependent industrialization strategy virtually came to a halt in the late 1970s and early 1980s when the liberal importation policy expanded the imports of finished goods to the detriment of domestic production. This led to relative decline in manufacturing production of exportable and thus, little diversification in products and production processes was achieved.

Likewise, a study on productivity growth in Nigeria via manufacturing sector is important for a number of reasons. First, there is a direct linkage between productivity growth and sustained economic growth. Secondly, Nigeria's development experience shows that past growth strategy based on factor accumulation is both infeasible and sub-optimal. The economic reality facing the country today requires a shift in emphasis to factor efficiency. Finally, higher productivity is also a key to poverty reduction.

Over the years, the industrial efforts of the Nigerian economic policies have been focusing on manufacturing as a way to diversify the economy away from the dependence on oil revenue. Until now, the impact of these efforts to promote manufacturing to sustain economic development is not fully examined. It is not known if manufacturing is the engine of non-oil economic growth in Nigeria. Moreover, the success of the efforts to enhance productivity and competitiveness of the manufacturing industry and its ability to create jobs in the market is linked to many important factors; among them is the education system, research in science and technology, and government policies, all of which are advancing very slowly in Nigeria.

\section{PROBLEMS}

Omanukwue (2005) pointed out that manufacturing sector become a complex activity, more so in the light of dynamic changes and innovations that have pervaded the global economy. In a developing economy like Nigeria, this becomes much more challenging given the desire and need to compete both domestically and internationally. Consequently, Government in 2004 launched an economic reform programme, the National Economic Empowerment and Development Strategy (NEEDS). There has been a strong concern especially for manufacturing and agriculture that the need to develop them among others has not been adequately met. There are numerous drawbacks to productivity growth in Nigeria and among them are the following; first, the absence of a consistent and long-term strategy for productivity improvement; secondly, overriding nature of the public sector in the economy despite the recent declaration of privatization as we are still struggling with who and by what means the country will enter into full privatization as private sector initiatives have not reached its expected state of operations; thirdly, the very weak corporate linkages among the various sectors of the economy -business linkages facilitate innovation, higher productivity through specialization and flexibility meeting customer needs, and enables economies of scale; fourthly, the weak linkage between the issue among economists and many researchers when attempting to investigate their relationship. (Majeed 2014) highlighted four possible propositions on a relationship between export and economic growth: export-led growth (ELG), growth-driven export (GDE), feedback relationship between export and economic growth, and finally it is possible that there is no relationship. Some of the researchers sighted and found unidirectional causality and some of them found bidirectional causality and of course some of them could not find any evidence for causality between export and GDP.

Kaldor (1966 and 1967) established that there is a link between the growth of manufacturing output and the growth of GDP in his first growth law i.e. Kaldor's first growth law. He put forward his theory by analyzing the slow growth of the British economy after World War II and saw the main reason for the weak performance in the growth potential of the manufacturing sector. The higher the growth rate in manufacturing (YM) was, the higher the overall growth rate (Y). This positive correlation was later called Kaldor's First Growth Law. Kaldor argued that neither the relatively big share of manufacturing nor its above-average productivity level cause this relation, but the existence of increasing returns. According to Kaldor, manufacturing sector has characteristics which make it the engine of growth for two main reasons. Firstly, manufacturing itself is subject to increasing returns, both at static and dynamic level, while land-based activities and petty services are subject to diminishing returns. Secondly, as the manufacturing sector expands, and draws labour from other sectors where there are diminishing returns, productivity in these activities rises automatically because the average product of labour is above the marginal product. Thus, the faster manufacturing 


\section{International Journal of Engineering Applied Sciences and Technology, 2019 \\ Vol. 4, Issue 5, ISSN No. 2455-2143, Pages 56-63 \\ Published Online September 2019 in IJEAST (http://www.ijeast.com)}

output grows, the fester the growth of productivity in the economy as a whole, which is the major source of GDP growth and living standards.

Kaldor's theory is a plausible one, but there are at least three major issues that need discussion. First, what drives manufacturing output growth in the first place? Second, where is the demand for output in the story? Third, the model is essentially "closed-economy'. There is no foreign trade; there is not balance of payments or foreign exchange constraint. There is a fairly easy answer to the first question which Kaldor (1996) himself discussed, namely that in the early stages of development, the major source of demand for manufacturing output must be the dominant agricultural sector, but in the later stages of development, export growth will take over.

However, Penelope and Thirlwall (2013) established that, the Kaldor first law of growth is open to another interpretation because it is apparent across countries that there is a close association between manufacturing output growth and export growth, and between export growth and GDP growth. He said before it could be concluded that there is a close association between manufacturing output and gross domestic product, manufacturing output must have influenced export.

\section{OBJECTIVES}

Objective of the research study is to assess the Kaldorian Law as related to manufacturing output, economic growth and exports in Nigeria.

\section{LITERATURE REVIEW}

Gilberto and Sueli (2008) analyzed the relation between manufacturing output growth and economic performance from a Kaldorian perspective by estimating Kaldor's first and second growth laws for a sample of eleven Latin American economies during the period 1980-2006. The results presented confirmed the '"manufacturing is the engine of growth" hypothesis, and suggested the existence of significant increasing returns in the manufacturing sector in the largest Latin American economies. Verdoorn's Law was confirmed in all exercises, with the estimated Verdoorn coefficient ranging from 0.31 to 0.48 . So we can conclude mat productivity growth seemed to respond positively to output growth in the manufacturing sector in the period of analysis.

Yongbok (2006) examined Manufacturing, Increasing Returns and Economic Development and tested the validity of the Kaldorian approach to growth and development in China during its reform period of 1979-2004. Study found from both data sets that the
Kaldorian hypotheses about economic growth are valid in China during the reform period.

Olorunfemi et al. (2013) examined manufacturing performance for sustainable economic development in Nigeria using Ordinary Least Square for the period from 1980 to 2008, The results indicated positive relationship between manufacturing and each of capacity utilization and import as 1 percent change in capacity utilization and import lead to 43081 -and 3.8 percent change in manufacturing respectively. However, there is a negative relationship between manufacturing and each of investment, exchange rate, and export a 1 percent change in investment, exchange rate and export led to $0.04,12729,0,3$ percent reduction in manufacturing respectively. The t-values for investment, capacity utilization and import were used to test the hypothesis that each coefficient is from 0 , This is rejected; since the t-value was lower than 1.96 (at 95\% confidence level). This showed that investment, capacity utilization and import were major determinants of manufacturing performance for the period. The study concluded that the key to reversing the poor performance of Nigerian manufacturing is to provide incentives for firms to become more exportoriented.

Loto (2012) investigated The Determinants of Output Expansion in the Nigerian Manufacturing Industries employing OLS for the period between 1980 and 2010. The results of the regression showed that manufacturing output expansion is positively related to real GDP growth rate and also to the per capita level of real GDP. This association is expected in the sense that if there is increase in real GDP, per capita real GDP will surely increase. If there is increase in per capita real GDP, there is tendency for consumption of manufactured goods to increase which will lead to increase in demand. In order to meet this increase in demand, output must expand. The results also revealed that there is inverse relationship between output expansion and capacity utilization in manufacturing which is not surprising. Low demand due to ineffective purchasing power caused by inflation will result into excess capacity. A negative relationship between this variable and manufacturing output expansion is not surprising, simply because, if inflation is growing there will be higher prices which could increase the value of output at the expense of lower capacity and lower demand. The significance of the study lies on the fact that if the determinants of output expansion in the manufacturing industries are known, then, policies could be introduced to take care of them and thereby strengthened the position of the manufacturing sector. This could lead to output expansion and employment generation 


\section{International Journal of Engineering Applied Sciences and Technology, 2019 Vol. 4, Issue 5, ISSN No. 2455-2143, Pages 56-63 \\ Published Online September 2019 in IJEAST (http://www.ijeast.com)}

Iraj et al. (2011) assessed the Manufacturing Sector and its Multiplier Effects on the South African Economy using a dynamic macro-econometric model. Results showed that a rand value investment spending in the Manufacturing sector will lead to notable changes in output, employment, exports and fiscal revenue. Given its linkages with other sectors in the economy, it should attract the first priority. Results from the simulation of the impact of a boost in manufacturing output (sustainable scenario) revealed the macro-economic implications of an accelerated manufacturing performance. These simulations show that a boost in the Manufacturing sector will have a considerable impact on the major macro-economic variables (household consumption, GDP, investment, etc.). An increase in the number of people employed under the sustainable scenario growth path will help alleviate unemployment in the country.

Shirazi and Abdul Manap (2005) examined the Export-Led Hypothesis: Further Econometric Evidence from South Asia using Co-integration and Multivariate Granger Causality tests. The results strongly supported a long run relationship among the three variables for all the countries under study, except Sri Lanka. The results also showed a feedback effect between imports and output growth for Pakistan, Bangladesh and Nepal, unidirectional causality from imports to output growth for Sri Lanka, but no causality for India. It also found feedback effects between exports and output growth for Bangladesh and Nepal. However, it showed unidirectional causality from exports to output growth in case of Pakistan and no causality in case of Sri Lanka and India. The results supported the export-Led growth hypothesis for Bangladesh, Pakistan and Nepal, but not for India and Sri Lanka. The study concluded by the way of recommendation that these countries should continue with the import of necessary raw material for value addition and needed technology to expand capacity and improve productivity to increase output growth.

Njoku, Okezie and Idika (2014) investigated the relationship between Nigeria's capital expenditure and the growth of the manufacturing sector. The ordinal least square method was used from 1971-2012, The results suggested that there is a positive relationship between the rate of growth of GDP, capital expenditure, money supply, openness of the economy, recurrent expenditure and manufacturing output in the country. In the light of the above, the papers recommended, among other things, government should increase the capital expenditure and reduce recurrent expenditure and also make sure that government funds are properly managed in a manner that it will raise the nation's production capacity and accelerate economic growth.

Ernest (2013) investigated the impact of macroeconomic factors on manufacturing productivity in Nigeria using Augmented Dickey Fuller (ADF) test and estimate error correction mechanism model over the period 1975-2010. The findings were reinforced by the presence of a long-term equilibrium relationship, as evidenced by the co-integrating equation of the VECM. The findings showed that credit to the manufacturing sector in the form of loans and advances and foreign direct investment have the capacity to sharply increase the level of manufacturing productivity in Nigeria, while broad money supply has less impact. The study, therefore, recommended that government must create "enabling environment" for manufacturers in the area of infrastructure, financial, legal and property rights. High cost of borrowing is due to high interest rate spread. Therefore, this study advocated a cut in margin between lending and deposit rates. For a resounding performance, the establishment of Micro finance Banks, Small and Medium Industries Equity Investment Scheme and Small and Medium Enterprises Development Agencies of Nigeria, Bank of Industry should be overhauled for development and improvement in the local production.

Akinmulegun and Oluwole (2013) studied the assessment of the contribution of manufacturing sector to economic growth in Nigeria in the era of globalization employing Ordinary Least Square (OLS) econometric technique on time series data of relevant variables of manufacturing Output. The study found that though Nigeria manufacturing sector benefited from globalization process, the level of the development in the sector was found to be highly negligible. Meaning that globalization exerts little impact on economic growth via manufacturing sector of the economy. The study recommended that efforts should be geared toward strengthening the macroeconomic, socio-infrastructural and institutional environment of the nation, thus bringing a good linkage between domestic and external institutions with the ultimate aim of properly harnessing funds so mobilized towards productive manufacturing sector of the economy.

Ayeni (2012) investigated an assessment of the profit of manufacturing firms in Nigeria during the period of global economic melt-down using Panel model analysis. Thirty one manufacturing firms were selected on a cross sectional basis for five years. The results showed that profitability across manufacturing firms in Nigeria is time variant. That is, profitability tends to be reduced during the period of economic melt - down. Profitability across manufacturing firm in 


\section{International Journal of Engineering Applied Sciences and Technology, 2019 \\ Vol. 4, Issue 5, ISSN No. 2455-2143, Pages 56-63 \\ Published Online September 2019 in IJEAST (http://www.ijeast.com)}

Nigeria responded negatively to global economic melt - down because of factors such as Technological changes, changes in government regulatory and / or tax policies, external effects such as wars, conflicts, etc which may probably affect the source of raw material. This impact varies from year to year, it was found to be lesser in 2009 and greater in 2007.

Sunday and Peter (2012) examined Analytical evaluation of cost elements and their influence on productivity of manufacturing firms with the use of Ordinary Least Square (OLS) method on the data obtained through questionnaire. The study revealed that three major categories of manufacturing costs affect the overall productivity of manufacturing companies; viz, raw materials, labour and overhead costs. This study also established that the ability or inability of manufacturing companies to properly control and minimize these costs has a direct bearing on how productive or unproductive these companies are. Basically on the finding, it was recommended that the major cost elements of material, labor and overhead should be individually managed in the light of overall productivity. Also manufacturing companies should pay closer attention to cost reduction, cost management and cost control in order to remain increasingly profitable.

Sangosanya (2011) empirically studied the dynamics of manufacturing firm's growth in Nigeria using panel analysis. The panel regression model employed emanated from the neoclassical, managerial, and optimum firm's size theories and the Gibrat's Law of Proportionate Effect Multi-stage sampling technique was used to survey 45 manufacturing firms quoted under the Nigerian Stock Exchange (NSE) between 1989 and 2008. The result revealed that manufacturing firms finance mix, utilization of assets to generate more sales, abundance of funds reserve and government intervention as indicated by Tobin's Q, operating efficiency, capital reserve and government policies are significant determinants of manufacturing firms' growth and dictated their dynamics in Nigeria. Also, that the Gibrat's component enhanced the growth rate of manufacturing firms' sales, profit and capital employed dynamically in the manufacturing sector.

Mouawiya (2010) studied The Role of Manufacturing in Promoting Sustainable Economic Growth in the GCC (Gulf Cooperation Council (GCC)) countries using panel co-integration techniques and macroeconomic data spanning from 1997 to 2007. The results showed that the importance of manufacturing or non-oil GDP in general was declining relative to the oil sectors in these countries. This results also showed that manufacturing is strongly linked to non-oil economic growth in the GCC countries over the long run, in a way that income and population were both important to stimulate manufacturing in the GCC countries, especially income. In the short run, manufacturing in the GCC countries has no significant effects on stimulating the growth levels of real non-oil GDP and that government spending might not be effective in terms of deriving the growth of non-oil GDP or stimulating diversification efforts in the GCC countries over the sample period.

Teshome (2014) studied the impact of manufacturing sector on economic growth in Ethiopia based on Kaldorian approach. Double log multiple regression equation was used between 1980 and 2009. The results indicated that the manufacturing sector in Ethiopia play the major role in structural transformation in the country. The following recommendations were preferred in relation to the results; the future economic growth in the country depends on the performances of the manufacturing sector in the country. The government should strengthen its current effort on development of the manufacturing sector in the country. With the dynamic nature of the global market, the government should apply innovative economic policy. The industrial policy should be implemented as per the plan with coordinated manner. The effectiveness of industrial zone development determines the structural transformation of the country. The private sector must improve their entrepreneurial skill to exploit the market economy in the country. The dependency of the manufacturing sector on imported material must be replaced with local resources or materials. This promotes the competitiveness of the local manufacturing sector that increases the impact of the sector in the economy.

\section{METHODOLOGY, DATA AND ANALYSIS}

\subsection{Kaldorian Law Model}

Kaldor's first law can be considered that GDP growth is governed by export growth, and export growth itself is a positive function of manufacturing output growth because of the favourable demand characteristics that manufactured goods have in world trade; specifically, their higher income elasticity of demand in world markets than other commodities (primary and tertiary). In other words (in linear form) if:

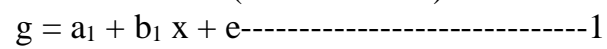

Where $g$ is the growth of GDP and $x$ is the growth of total exports, and

$$
\mathrm{x}=\mathrm{a}_{2}+\mathrm{b}_{2} \mathrm{gm}+\mathrm{e} \text {---------------------------2}
$$


Where gm is the growth of manufacturing output, then substituting (2) into (1) gives:

Or

$$
\mathrm{gGDP}=\mathrm{a}_{1}+\mathrm{a}_{2} \mathrm{~b}_{1}+\mathrm{b}_{1} \mathrm{~b}_{2}--------------------3
$$

$$
\mathrm{g}=\mathrm{a}+\mathrm{b} \text { gm-----------4 }
$$

Where $a=a_{1}+a_{2} b_{1}$ and $b=b_{1} b_{2}$

The interpretation is different in this manner The extent to which manufacturing output growth promotes a faster growth of GDP depends on the impact of manufacturing output growth on total export growth and the extent to which export growth governs output growth (bi) -sometimes called the dynamic Harrod trade multiplier result (McCombie and Thirlwall, 1994, 2002; Thirlwall, 2011).

\begin{tabular}{|l|l|l|l|l|}
\hline Variable & Coefficient & Std. Err. & $\begin{array}{l}\text { t- } \\
\text { Statisti } \\
\text { c }\end{array}$ & Prob \\
\hline $\mathrm{C}$ & $\mathbf{4 1 3 7 . 8 1 4}$ & $\mathbf{2 0 0 5 . 2 3 2}$ & $\begin{array}{l}\mathbf{2 . 0 6 3 5 0} \\
\mathbf{9}\end{array}$ & $\begin{array}{l}\mathbf{0 . 0 4 6} \\
\mathbf{8}\end{array}$ \\
\hline $\begin{array}{l}\text { Manufact } \\
\text { uring }\end{array}$ & $\mathbf{1 0 . 8 5 2 7 0}$ & $\mathbf{0 . 6 7 4 2 7 8}$ & $\begin{array}{l}\mathbf{1 6 . 0 9 5 2} \\
\mathbf{8}\end{array}$ & $\begin{array}{l}0.000 \\
0\end{array}$ \\
\hline
\end{tabular}

R-Squared

0.883982

Adjusted R-Squared

0.880570

F - Statistics

259.0580

Prob. (F - Statistic)

0.000000

Durbin - Watson Stat

$\mathbf{0 . 3 0 9 3 5 5}$

Source: Authors' computation using E-view, 2019.

From the table 1 above, Durbin-Waston statistic value was (0.309355), this is in the range of 0 and 2. This revealed that there is absence of first order serial correlation problem of regression in the model and proved that autocorrelation problem did not exist. The coefficient of determination (R-Squared) was $(0.883982)$ which indicated that explanatory variable explained about 88 percent of explained variation that occurred in explained variable. This implied that about 12 percent of the changes in economic growth are attributable to factors not included in this model. The F-Statistic calculated is (259.0580), which tested the overall significance of the variables, is relatively high.

Also, the table above revealed that the impact and relationship between indicator of economic growth and manufacturing. The coefficient of manufacturing to Gross Domestic Product which is (10.85270) implied that 1 unit increase in manufacturing led to increase in Gross Domestic Product Growth Rate (GDP). Likewise, t-statistics of
(16.09528) and P-values of $\mathbf{0 . 0 0 0 0 ~ i n d i c a t e d ~ t h a t ~}$ proportion of the manufacturing output actually has greater impact on gross domestic product and that the relationship between the two variables was highly significant.

\begin{tabular}{|l|l|l|l|l|}
\hline Variable & $\begin{array}{l}\text { Coeffici } \\
\text { ent }\end{array}$ & $\begin{array}{l}\text { Std. } \\
\text { Err. }\end{array}$ & $\begin{array}{l}\text { t- } \\
\text { Statisti } \\
\text { c }\end{array}$ & Prob \\
\hline C & - & 878.49 & - & 0.00 \\
& 2669.87 & 83 & 3.0391 & 45 \\
& 0 & & 29 & \\
\hline $\begin{array}{l}\text { Manufactu } \\
\text { ring }\end{array}$ & 2.71927 & 0.2954 & 9.2052 & 0.00 \\
8 & 03 & 87 & 00 \\
\hline
\end{tabular}

R-Squared

0.713654

Adjusted R-Squared

0.705232

F - Statistic

84.73731

Prob. (F - Statistic)

0.000000

Durbin - Watson Stat

0.289018

Source: Authors' computation using E-view, 2019.

From table 2 above, Durbin-Waston statistic value was (0.289018), this is in the range of 0 and 2 . This revealed that there is absence of first order serial correlation problem of regression in the model and proved that autocorrelation problem did not exist. The coefficient of determination (R-Squared) was $(0.713654)$ which indicated that explanatory variable explained about 71 percent of explained variation that occurred in explained variable. This implied that about 29 percent of the changes in export are attributable to factors not included in this model. The F-Statistic calculated is (84.73731), which tested the overall significance of the variables, is relatively high.

Also, the table above revealed that the impact and relationship between growth in export and manufacturing. The coefficient of manufacturing to export which was (2.719273) and it implied that 1 unit increased in manufacturing led to increase in Growth in export Likewise, t-statistics of (9.205287) and Pvalues of $\mathbf{0 . 0 0 0 0}$ indicated that proportion of the manufacturing output actually has greater impact on gross domestic product and that the relationship between the two variables was highly significant. The above results were in consistence with the work of (Penelope and Thirlwall, 2013). 


\section{International Journal of Engineering Applied Sciences and Technology, 2019 Vol. 4, Issue 5, ISSN No. 2455-2143, Pages 56-63 \\ Published Online September 2019 in IJEAST (http://www.ijeast.com)}

\section{CONCLUSION}

This is the first attempt where Kaldorian approach is applied in Nigeria with new interpretation to establish the link between manufacturing output growth and export growth between 1981 to 2016 and to provide an alternative open economy interpretation of the strong link between manufacturing output growth and GDP growth (Kaldor's first law) through the impact that manufacturing output growth has on export growth, and the effect that export growth has on GDP growth by providing foreign exchange for imports and relaxing a balance of payments constraint on demand. All countries of the world grow fast if they have an export structure controlled to record increase in production that is capable of meeting the external teeming demand of other countries of the world far beyond normal local consumption. Also, countries producing manufactured goods with a high-income elasticity of demand in the world markets will have a higher growth of exports and a higher growth of GDP which invariably will have lasting positive impact on both balance and term of trade.

To establish an acceptable explanation of the strong link between manufacturing output growth and GDP growth, there is a need to look beyond a closed economy but because of the increasing capacity of the manufacturing sector to fulfill economic assumption of increasing returns to scale that will transcend usual economic phenomenon (closed economy) into an open economy where productivity of manufacturing sector could be exported to other countries. Kaldor (1970) chose to concentrate on the static and dynamic returns to scale that characterize manufacturing more than agriculture and services, but he was also aware of the role of exports in the growth process, particularly for very open economies such as regions. In fact, Kaldor cumulative causation model (Kaldor, 1970) has both export growth and returns to scale in manufacturing as integral elements. In his basic growth laws, however, exports are missing but to proffer better and acceptable interpretation, there is a need to include exports in the model if manufacturing output will be established to have impact on nation's economic growth. What we have shown here is that, it is possible to estimate a similar elasticity of GDP growth with respect to manufacturing output growth which have induced productivity growth to satisfy external demand. And as a result, it paved way for the two structural equations linking export growth to manufacturing output growth and GDP growth to export growth. Finally, it could be established that Kaldorian law with new interpretation is held in Nigeria because, it is apparently seen across all countries of the world that there is close association between the GDP and Manufacturing output. Whereas, the rationale behind the new interpretation is that before it could be established that there is an impact of manufacturing output on economic growth, there must have been impact of manufacturing output on exports denoting that excess productions are sold abroad. It could also be said that closed economy model led to open economy model. Without mincing words Kaldorian approach is held in Nigeria with new interpretation.

\section{REFERENCES}

1. Akinmulegun S. O., and Oluwole F. O. (2013)'. An assessment of the Nigerian manufacturing sector in the era of globalization. Am. J. Soc. Mgmt. Sci., 2013, 5(1): (pg.27-32)

2. Ernest S. O., (2013)'. Macroeconomic Variables and the Productivity of the Manufacturing Sector in Nigeria: A Static Analysis Approach. Journal of Emerging Issues in Economics, Finance and Banking (JEIEFB) An Online International Monthly Journal Volume: 1, (pg. 362-380).

3. Gilberto L. and Sueli M. (2008)'. Manufacturing

a. Industry and Economic Growth in Latin

b. America: A Kaldorian Approach. CEDEPLAR / Federal University of Minas Gerais, Brazil.

4. Inegbenebor (1995)'. Size, Structure and Performance

a. of Private Nigeria Manufacturing

b. Enterprises. Nigerian Journal of Economics and Social Studies, Vol. 37.

5. Iraj A. et al (2011)'. Assessing the Manufacturing Sector and its Multiplier Effects on the South African Economy. The Research Division Pan-African Investment \& Research Services Johannesburg, South Africa 30 November, 2011.

6. Kaldor N (1966)'. Causes of the Slow Rate of Economic Growth of the United Kingdom: An Inaugural Lecture. Cambridge: Cambridge University Press.

7. Loto M.A. (2012)'. The Determinants of Output Expansion in the Nigerian Manufacturing Industries. Journal of Emerging Trends in Economics and Management Sciences (JETEMS) 3(6): 991996. Scholarlink Research Institute Journals, 2012 (Pg. 2141- 7024) 
8. Loto M.A. (2012)'. Global Economic Downturn and the Manufacturing Sector Performance in the Nigerian Economy (A Quarterly Empirical Analysis). Journal of Emerging Trends in Economics and Management Sciences (JETEMS), (Pg. 3845)

9. Majeed A. H. (2014)'. Economic Growth, Exports and Imports in Pakistan: Granger Causality Analysis. Economic Growth in Pakistan. (Pg. 31-62)

10. Mouawiya Al Awad (2010)'. The Role of Manufacturing in Promoting Sustainable Economic Growth in the GCC. Institute for Social \& Economic Research, working paper No.4,

11. Njoku, A.C, Okezie A. I. and Idika, N. (1014)'. Is Government Capital Expenditure Productive? Evidence from Nigerian Manufacturing Sector (1971-2012). Journal of Educational and Social Research MCSER Publishing, Rome-Italy. (pg. 143-154)

12. Olorunfemi S. et al. (2013), "Manufacturing Performance in Nigeria: Implication for Sustainable Development". Asian Economic and Financial Review, 2013, 3(9): 1195-1213

13. Penelope P. and Thirlwall A. P. (2013)'. A New Interpretation of Kaldor's First Growth Law for Open Developing Economies. School of Economics, University of Kent, Canterbury, (pg. 1-16).

14. Roslina M. I. (2005)'. Total Factor Productivity Growth, Efficiency and Technological Progress of The Malaysian Manufacturing Sector. Abstract of thesis presented to the Senate of University Putra Malaysia in fulfillment of the requirements for the degree of Doctor of Philosophy

15. Sangosanya A.O. (2011), "Firms Growth Dynamics in Nigeria's Manufacturing Industry: A Panel Analysis". Journal of Applied Econometric Review, Vol. 1, No. 1 (Pg. 1-18)

16. Shirazi N.S. and Abdul Manap T.A. (2005)'. Export-Led Hypothesis: Further Econometric Evidence from South Asia. The Developing Economies, (Pg. 472- 488).

17. Sunday A. E. and Peter A. O, (2012), "Analytical evaluation of cost elements and their influence on productivity of manufacturing firms Journal of Finance and Investment Analysis, vol.1, no.3, 2012, (Pg.171-180)

18. Teshome A. (2014), "Impacts of Manufacturing Sector on Economic Growth in Ethiopia: A Kaldorian Approach. Journal of Business Economics and Management Sciences, (pg 1-8)

19. Yongbok J. (2006) "Manufacturing, Increasing Returns and Economic Development in China, 1979-2004: A Kaldorian Approach". Department of Economics Working Paper Series, Working Paper -08 